\title{
The unfunded costs incurred by patients accessing plastic surgical care in Northern Saskatchewan
}

\author{
Jessica L Robb MD¹, Brian J Clapson MD²
}

JL Robb, BJ Clapson. The unfunded costs incurred by patients accessing plastic surgical care in Northern Saskatchewan. Plast Surg 2014;22(2):88-90.

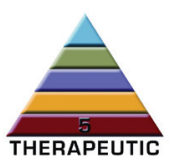

The Canadian health care system was designed to ensure that all Canadian citizens would receive equal access to health care. However, in rural areas of Canada, patients are required to travel long distances and pay significant out-of-pocket expenses to access health care.

The present study attempted to quantify the added out-of-pocket costs that rural Saskatchewan residents must pay to receive plastic surgical specialist care compared with urban residents of Saskatoon. A cost analysis was performed to generate a numerical value that would represent a minimum cost for patients travelling from three different locations within the province. The cost analysis performed in the present study approximated that the unfunded costs for common plastic surgical procedures are, at a minimum, 30 times greater for rural patients in La Ronge compared with their urban counterparts in Saskatoon.

The fundamental principle of the Canadian health care system is equal access to necessary health care for all Canadians. Despite this, inequalities persist. The present cost-analysis study demonstrated that the unfunded (out-of-pocket) expenses for rural Saskatchewan patients seeking plastic surgical treatment is significantly higher than for their urban counterparts. These unfunded costs represent a significant barrier to health care access in Canada and serve to propagate inequalities in the nation's heath care system.

Key Words: Aboriginal medicine; Canadian health care system; Health care delivery; Rural medicine; Unfunded medical expenses

In Canada, health services are managed by the Canada Health Act 1 (CHA), which ensures that treatments by primary care physicians, specialists, as well as surgeries and hospital stays, are all covered through provincial health insurance plans (1). The CHA ensures that all citizens of Canada receive necessary health care, free of charge, regardless of economic status. Despite this, ongoing inequalities in access to health care in Canada continue to exist (2). Specifically, studies have demonstrated that inequalities exist among socioeconomic groups, as well as between rural and urban populations $(3,4)$.

In Saskatchewan, the majority of specialist care is located within the two largest cities - Saskatoon and Regina - with populations of 284,000 and 226,300, respectively (5). The province itself is located in the centre of Canada, with a geographical area of $651,062 \mathrm{~km}^{2}$. As of October 1, 2013, the estimated population of Saskatchewan was $1,114,170$, with $35 \%$ of the population residing in rural areas (6). In the field of plastic surgery, all of the practicing plastic surgeons are located within the two main urban centres.

Individuals requiring plastic surgical care in Saskatchewan who live outside of these two cities must, therefore, travel varying distances to receive treatment. The burden of this additional travel is a significant barrier to health care access and is often underestimated. The present study attempted to quantify the added out-of-pocket costs that rural Saskatchewan residents must pay to receive plastic surgical specialist care compared with urban residents of Saskatoon and Saskatchewan.

\section{Les coûts non financés engagés par les patients qui reçoivent des soins en chirurgie plastique au nord de la Saskatchewan}

Le système de santé canadien a été conçu pour garantir à tous les citoyens canadiens l'égalité d'accès aux soins. Cependant, dans les régions rurales du Canada, les patients doivent parcourir de longues distances et payer euxmêmes des frais importants pour accéder aux soins.

La présente étude visait à quantifier les coûts personnels supplémentaires que les habitants des régions rurales de la Saskatchewan doivent payer pour recevoir des soins spécialisés en chirurgie plastique par rapport aux habitants de la région urbaine de Saskatoon. Les chercheurs ont effectué une analyse des coûts pour obtenir une valeur numérique représentant le coût minimal pour les patients qui proviennent de trois endroits différents de la province.

L'analyse des coûts effectuée dans la présente étude a établi que les coûts non financés des interventions de chirurgie plastique les plus courantes étaient au moins trente fois plus élevés pour les patients des régions rurales de La Ronge que pour leurs homologues de la région urbaine de Saskatoon.

L'égalité d'accès aux soins nécessaires pour tous les Canadiens est le principe fondamental du système de santé canadien. Pourtant, des inégalités demeurent. La présente étude d'analyse des coûts a démontré que les dépenses non financées (personnelles) des patients des régions rurales de la Saskatchewan qui reçoivent des soins en chirurgie plastique sont beaucoup plus élevées que celles de leurs homologues des régions urbaines. Ces coûts non financés constituent un obstacle important à l'accès aux soins au Canada et contribuent à perpétuer les inégalités au sein du système de santé.

\section{METHODS}

The present study performed a cost analysis of unfunded costs (outof-pocket expenses) for hypothetical patients residing in three locations: Saskatoon (urban centre); Prince Albert (regional centre); and La Ronge (rural centre). A cost analysis for each of these areas was also performed for three common plastic surgery procedures: mandibular open reduction and internal fixation (emergent surgery); breast reduction (elective surgery); and carpal tunnel release (sameday surgery). All procedures in the present cost analysis model were performed at the tertiary teaching hospital in Saskatoon.

In this model, the authors assumed the unfunded costs arose solely from travel and food. Food cost was estimated to be $\$ 50.00$ per day of travelling. Therefore, this cost applied only to the regional and rural patients.

Travel costs were calculated for two possible scenarios: private transportation and public transportation. For private transportation, costs were calculated to be a mean of $\$ 0.51 / \mathrm{km}$. This was based on annual industry average costs in Saskatchewan for fuel consumption $(\$ 2,086.00)$, insurance $(\$ 1,470.00)$, license and registration (\$113.00), and depreciation and maintenance $(\$ 6,629.00)$ (7). An additional $\$ 15.00$ per day was calculated for private transportation parking cost.

Public transportation costs were calculated for La Ronge and Prince Albert to Saskatoon based on fares from the Saskatchewan

${ }^{1}$ Department of Surgery, Division of Plastic Surgery, University of Alberta, Edmonton, Alberta; ${ }^{2}$ University of Saskatchewan, Saskatoon,

Saskatchewan

Correspondence: Dr Jessica L Robb, Department of Surgery, Division of Plastic Surgery, University of Alberta, 2D.02 Walter Mackenzie Health

Science Centre, 8440-112 Street, Edmonton, Alberta T6G 2B7. Telephone 780-407-1591, e-mail jrobb1@ualberta.ca 
TABLE 1

Unfunded costs for patients using private transportation

\begin{tabular}{lccc}
\hline & \multicolumn{3}{c}{ Total cost, \$ } \\
\cline { 2 - 4 } City (Saskatchewan) & $\begin{array}{c}\text { Mandibular } \\
\text { fracture }\end{array}$ & $\begin{array}{c}\text { Breast } \\
\text { reduction }\end{array}$ & $\begin{array}{c}\text { Carpal tunnel } \\
\text { release }\end{array}$ \\
\hline Saskatoon & 45.00 & 90.00 & 75.00 \\
Prince Albert & 629.52 & $1,259.04$ & $1,049.20$ \\
La Ronge & $1,366.98$ & $2,733.96$ & $2,278.30$ \\
\hline
\end{tabular}

TABLE 2

Unfunded costs for patients using public transportation

\begin{tabular}{lccc}
\hline & \multicolumn{3}{c}{ Total cost, \$ } \\
\cline { 2 - 4 } City (Saskatchewan) & $\begin{array}{c}\text { Mandibular } \\
\text { fracture }\end{array}$ & $\begin{array}{c}\text { Breast } \\
\text { reduction }\end{array}$ & $\begin{array}{c}\text { Carpal tunnel } \\
\text { release }\end{array}$ \\
\hline Saskatoon & 0.00 & 0.00 & 0.00 \\
Prince Albert & 318.30 & 636.60 & 530.50 \\
La Ronge & 597.30 & $1,194.60$ & 995.50 \\
\hline
\end{tabular}

Transportation Company (8). Public transportation costs for residents of Saskatoon were assumed to be negligible.

The emergent mandibular fracture repair consisted of three visits to the Saskatoon hospital: initial presentation to the emergency department followed by immediate surgery; a follow-up clinic visit; and a second follow-up clinic visit. The elective breast reduction procedure consisted of six visits to the Saskatoon hospital: initial office presurgery visit; surgical procedure; and follow-up visits at one, three, five and 12 weeks postoperatively. Finally, the carpal tunnel release consisted of five visits to the Saskatoon hospital: initial assessment; nerve conduction studies; surgical procedure; and two follow-up visits. The pattern of care and the number of visits were based on information provided from practicing surgeons in Saskatoon.

\section{RESULTS}

The distance for patients residing in La Ronge, Prince Albert and Saskatoon to the treatment hospital was estimated to be $383 \mathrm{~km}, 142 \mathrm{~km}$ and $0 \mathrm{~km}$, respectively (9). Table 1 summarizes the total unfunded costs for patients using private transportation for all of the procedures describe in the study. Similarly, Table 2 summarizes the total unfunded costs for patients using public transportation. From these data, it is evident that all procedures require more unfunded costs for nonurban dwellers, regardless of whether private or public transportation is used.

Comparing Tables 1 and 2, it is also clear that private transportation costs are greater than public transportation costs across the same procedure. For example, the cost for a patient living in Prince Albert to have a mandibular fracture repaired using public transportation is $\$ 318.30$, compared with $\$ 629.52$ if private transportation is used.

Considering Figure 1, it is also evident that unfunded costs are much higher for patients living in La Ronge compared with those living in Saskatoon.

\section{DISCUSSION}

The present project was designed to highlight the unfunded costs incurred by patients travelling within the province of Saskatchewan while seeking plastic surgical treatment. The cost of travel and food for several common plastic surgical procedures was calculated to yield a numerical value to the personal costs paid by the patients. Three centres with varying distances to the location of treatment were compared.

Saskatoon was chosen to highlight the costs for individuals who reside within an urban centre, complete with a tertiary treatment facility. La Ronge was selected to represent a characteristic rural community in Northern Saskatchewan, home to a large Aboriginal population.

In 2009, Mathews et al (10) published a study that investigated how important out-of-pocket costs were to rural patients' cancer care

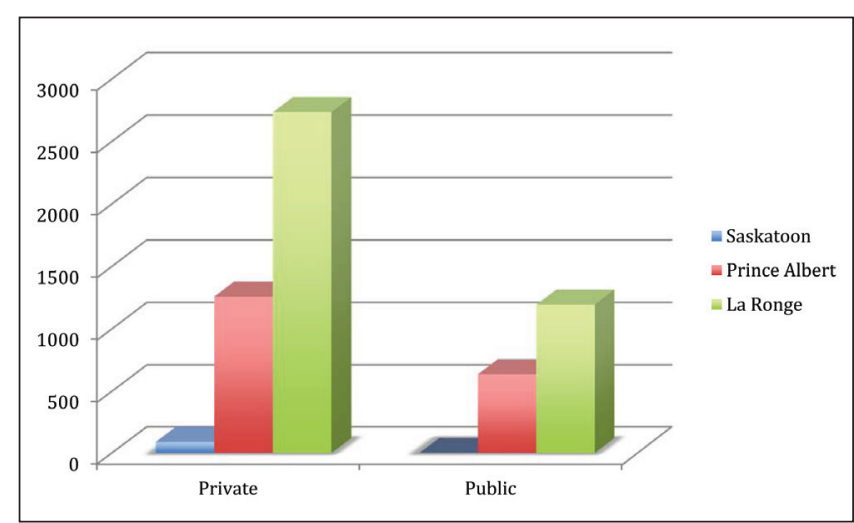

Figure 1) Unfunded costs for breast reduction in three selected cities in Saskatchewan

decisions. The study surveyed 484 residents of Newfoundland and Labrador and found that rural residents of the province were more likely to report that travel costs (OR 1.79) and child care costs (OR 2.33) were 'important' in cancer care treatment decisions compared with their urban counterparts. These unfunded costs may have a significant impact on the lives of rural patients. Although health care workers are often aware that travel costs are a significant burden to patients living abroad, the actual monetary figure this represents is rarely mentioned.

The total unfunded costs a patient is faced with when seeking health treatment is also highly variable. For example, if a patient has children and requires child care while in hospital, the situation can quickly escalate. Furthermore, surgeons will frequently recommend that patients remain close to the treatment facility for $24 \mathrm{~h}$ in case of emergencies. If nonurban dwellers require overnight accommodations at a hotel for medical reasons or because the distance to travel home requires a full day of travel, the unfunded cost barrier may be so large that rural patient may decide to not seek treatment at all. The present study focused on basic travel and food costs in an attempt to provide an unbiased representation of the unfunded costs paradigm for various residents of Saskatchewan.

As of 2006, the mean total annual income per family in Saskatchewan was $\$ 65,120$ (5). In contrast, in the northern community of La Ronge, with adjacent First Nations land, the annual household income was $\$ 56,118$ (5). In their study, the Conference Board of Canada stated that Aboriginal people were an at-risk group of low income in Canada (11). The out-of-pocket cost to receive health care puts extra financial burden on an at-risk population that already has a lower income.

The cost analysis performed in the present study approximated that the unfunded costs for common plastic surgical procedures are, at a minimum, 30 times greater for rural patients in La Ronge compared with their urban counterparts in Saskatoon.

\section{CONCLUSION}

The fundamental principle of the Canadian health care system is equal access to necessary health care for all Canadians. Despite this, inequalities persist. The present cost-analysis study demonstrated that the unfunded (out-of-pocket) expenses for rural Saskatchewan patients seeking plastic surgical treatment is significantly higher than for their urban counterparts. These unfunded costs represent a significant barrier to health care access in Canada and serve to propagate inequalities in the nation's heath care system.

\section{REFERENCES}

1. Madore O. The Canada Health Act: Overview and Options, Pariliament Information and Research Service, revised 2005.

2 Curtis LJ. Health care utilization in Canada: Twenty-five years of evidence. Canadian Public Policy 2008;34:65.

3. Faulds J, Bell NJ, Harrington DM, et al. Socioeconomic and geographic disparities in access to endovascular abdominal aortic aneurysm repair. Ann Vasc Surg 2013;27:1061-7. 
4. Harrington DW, Wilson K, Rosenberg M, Bell S. Access granted! barriers endure: Determinants of difficulties accessing specialist care when required in Ontario, Canada. BMC Health Serv Res 2013;13:146.

5. Aday LA, Andersen R. A framework for the study of access to medical care. Health Serv Res 1974;9:208-20.

6. Government of Saskatchewan. Bureau of statistics. <www.stats.gov. sk.ca> Updated 2013. (Accessed December 18, 2013).

7. CAA. Driving costs. <http://caa.ca/car_costs/> Updated 2013 (Accessed December 18, 2013).

8. STC. Schedule and fare finder. <www.stcbus.com/Passenger/ps_ passengerschedulesfinder.aspx $>$ Updated 2013 (Accessed December 18, 2013).
9. Canada Distances Online. Road distances Canada. <http://canada. distancesonline.com/> Updated 2012 (Accessed December 18, 2013).

10. Mathews M, West R, Buehler S. How important are out-of-pocket costs to rural patients' cancer care decisions? Can J Rural Med 2009; 14:54-60.

11. Conference Board of Canada. Canada income inequality. <www.conferenceboard.ca/hcp/hot-topics/caninequality.aspx> Updated 2013 (Accessed December 18, 2013). 